Case report

\title{
The methodology of body approach for autists - a case study
}

\author{
Elvio Marcos Boato ${ }^{1}$ (1) , Augusto Parras Albuquerque ${ }^{2}$ (1) , Soraya Valenza Diniz ${ }^{2}$ (D), \\ Graciele Massoli Rodrigues ${ }^{3}$
}

\begin{abstract}
${ }^{1}$ Universidade Católica de Brasília, Brasilia, DF, Brasil; ${ }^{2}$ Secretaria de Estado de Educação do Distrito Federal, Brasilia, DF, Brasil; ${ }^{3}$ Universidade São Judas Tadeu, Escola Superior de Educação Física de Jundiaí, Jundia, SP, Brasil
\end{abstract}

\begin{abstract}
Introduction: The Autistic Spectrum Disorder (ASD) is characterized by persistent deficits in communication and social interaction in multiple contexts and restricted and repetitive patterns of behavior, interests, or activities. Aim: The objective of this work was to present and analyze a program that offers specialized educational service in Physical Education and Art (dance), proposed for a student with ASD, based on a body approach methodology. Methods: A case study was carried out with a student with ASD for three years of corporal intervention practice with two weekly sessions at the Aquatic Activities and Body Expression sessions in a community project. Conclusion: It was possible to observe that the student demonstrated significant improvements in social interaction, communication, and development of the corporal scheme, confirming the effectiveness of the presented corporal intervention.
\end{abstract}

Keywords: autism spectrum disorder; physical education; case study.

\section{Signaling a Beginning}

According to the Diagnostic and Statistical Manual of Mental Disorders - DSM-V $V^{1}$ Autistic Spectrum Disorder (ASD) is used by persistently disabled people in communication and social interaction in restricted and repetitive contexts and patterns of behavior, interests, or activities.

In people with ASD, physical activity levels are lower than those recommended by health organization ${ }^{2-4}$, with compromised motor skills and poor physical health. In addition, tha majority of the activities given to people with ASD are based on game-based exercise training program that show not enough to improve their quality of life ${ }^{4}$. This framework presents issues such as social commitment, emotional and physical control, attributed to individuals with $\mathrm{ASD}^{5}$, or that leads to problems in the development of perceptual motor skills ${ }^{6}$.

Therefore, it is fundamental for psychomotor stimulation that people with ASD to engage in physical activity program to minimize the difficulties of interaction and communication ${ }^{7-13}$ present at ASD, decrease as stereotypes ${ }^{10,14}$, improving behavior ${ }^{3}$, such as motor skills ${ }^{6,7}$, quality of sleep, and cognition ${ }^{10}$.

Evidence highlights the importance of physical education for the development of social interaction and communication in children with ASD, considering that inactivity and non-access to programs that stimulate psychomotor development may lead to problems in these aspects ${ }^{12}$. Thus, it is necessary to stimulate conscious motor acts in people with ASD to provide them more time to understand and perform more complex movements ${ }^{15}$, without; however, trying to contain spontaneous movements or blaming non-moving movements appropriate that can be presented since they present themselves as the possible form of motor communication for the child with ASD at a given moment ${ }^{16}$.
The importance of starting psychomotor stimulation in the first months of a children's life has been highlighted since the lower the level of physical activity can bring more significant problems to them ${ }^{17,18}$. Indeed, evidence has shown the importance of motor stimulation, including basic coordination and strength exercises, as therapeutic interventions for children with ASD9.

Specifically, in relation to social interaction and communication, important results from Physical Education programs has been demonstrated in people with $\mathrm{ASD}^{8,12,19}$. Thus, it is considered that it is from the body and the stimulation of their expressions that individuals with ASD can organize and understand the environment, because the body movement influences their usual behavior, being an important factor of your temperament and communication ${ }^{20}$.

This study aims to contribute to specialized educational assistance to children with ASD. This case study was conducted with a student with ASD who belongs to a community research Project in Educational Assistance Specialized in Physical Education and Art (dance). The proposal was designed based on the attendance in two workshops: body expressions/dance and swimming, which worked within a perspective of integral development of the individual, through playfulness.

The proposal is justified by the need to conduct empirical studies that seek alternatives for specialized educational assistance in Physical Education for people with ASD, given the scarcity of data in the literature. In this sense, the objective of this work was to present and analyze a program of specialized educational assistance in Physical Education, proposed for a student with ASD, based on a body approach methodology, based on a pedagogical intervention proposal, which seeks the integral development of individuals. 


\section{Theoretical support}

The theoretical framework of this work was based on brings Henri Wallon's theory ${ }^{20-24}$, that supports its pedagogical proposal, mainly in aspects related to the role of emotions in the development of the individual and its relationship with the environment. Relational psychomotricity is also considered, a method of approach which supports a large part of the performance in the Workshops ${ }^{25-29}$.

The aquatic activity was chosen as a facilitating environment for psychomotor practice, in accordance with a previous study ${ }^{30}$. Briefly, in the water both postural and motor re-learning can happen. Besides, the student can "enjoy the condition of equality and the feeling of freedom, allowing the optimization of motor skills, differently from what happens on land"

With reference to the difficulties of people with ASD in maintaining relationships and communicating with each other, the aquatic environment can also favor a closer relationship and a more intense body dialogue due to the initial insecurity that this situation offers in certain situations of imbalance, moments in which the teacher can approach and establish a communication.

The Body Expression/Dance work sought to refine the relationship between Art and Physical Education teaching, addressing aspects of artistic expression and its relationship with psychomotor development, based on the languages of dance, body expression and theater. In this perspective, the student was seen as a living being who experiences his life, knowing and making himself known as he takes possession of the reality that surrounds him. Art is, therefore, a way of knowing, which helps in understanding this reality and together with Physical Education creates a space for free, spontaneous and liberating psychomotor expression $^{31}$.

It was considered that the person with ASD needs to experience his own body in sensorimotor activities that bring the notion of the tonic condition in the relationship with her/ himself, with the other and with the environment ${ }^{31}$, after all, the tone, besides translating the organism's emotional experience, is the foundation of praxic activities ${ }^{32}$. Thus, the student was allowed to move freely in many moments of the classes, including through stereotypes, in a sensorial motor that was latent in its behavior. Thus, when executing these seemingly disorganized movements, he sought answers from the teacher who he was always receptive because he believed that performing these exercises could bring better organization and overcoming them.

It was also necessary to emphasize, the need for the student to practice the experience of dance as a collective manifestation in cultural production and aesthetic appreciation, with choreographies being presented to the families of the community Project. This experience, the student had the opportunity to be involved a different form of emotion and to show, in his language, the possibility and beauty of each person's uniqueness.

Thus, it was considered that people with ASD need quality educational assistance that seeks the maximum development of their potential since they are able to communicate and express themselves effectively, with the necessary basic stimuli.

\section{Methodological path}

This case report was carried out according to $\mathrm{Yin}^{33}$, is an empirical research "that investigates a contemporary phenomenon within its real-life context, especially when the limits between the phenomenon and the context are not clearly defined".

An analysis of the processes adopted in the pedagogical intervention was carried out with a 9-year-old student diagnosed with Autistic Spectrum Disorder (ASD).

This study was approved through the opinion of the Research Ethics Committee of the Catholic University of Brasília (CAEE 67645217.7.0000.0029).

The two teachers from the two workshops proposed to the student and his mother also participated in the research.

The research was substantiated through pedagogical interventions that took place over a period of three years within the activities of the Community Research Project in Specialized Educational Care in Physical Education and Art (Dance) for people with disabilities. The student participated in two workshops, Aquatic Activities (AA) and Body Expression (BE), being attended individually, with two weekly sessions of 35 minutes each. From the fourth semester of activities, he was treated together with a student with Down Syndrome at a similar age. In addition to the services offered, he participated in the events held in the Community Project including four swimming festivals and three dance shows.

For the collection of information, reports of participant observations prepared by the researcher, interviews, questionnaire, and the teachers' class diary were used. From these documents, a qualitative analysis was carried out that implied an "emphasis on processes and meanings that are not examined or measured rigorously, in terms of quantity, volume, intensity or frequency"34.

The observations of the activities were made by the researcher with the collaborating teachers who held discussions for the analysis of the pedagogical practices used in the workshops, with verification of the student's development and definition of the intervention proposals. Interviews were carried out with the teachers and the student's mother throughout the research period, in order to obtain information about the student's behavior and development, in order to know the perceived problems and clarify them.

The researcher followed the assistance during the three years of the study, always talking to the student's mother with the intention of obtaining information about the child's participation in pedagogical interventions, and these conversations were always transcribed and served as a basis for the discussion of the work.

At the end of the study, the mother answered a written questionnaire that aimed to verify her impressions about the results presented at the end of the pedagogical intervention and the information obtained served as a basis for the description of the steps followed in the interventions, with a final report of the same ones being presented. with the direct participation of the two collaborating teachers. After that, a discussion was made to get the next steps, retrieving facts related to pedagogical interventions that allowed an analysis of the process triggered in the workshops, in addition to issues related to student development. 


\section{Life route}

At the beginning of the intervention, the student had screams, physical aggression, difficulty in socializing and understanding limits, not responding to the commands of the Teachers. Sometimes he made contextualized comments, being curious and observant, with a low tolerance for frustration, which made the assistance difficult. He accepted certain commands and sometimes refused them for no apparent reason.

At the beginning of the work in the aquatic activities, he was relatively familiar with the water, but he showed insecurity and fear for the depth of the pool, where he only came in accompanied by his mother and wearing a life jacket. At the end of the study, dives, previously refused, improved, but still represented an impediment to more efficient swimming. He already performed glides and kicks autonomously in the prone position and with the help of a board in the supine position, showing pleasure in the activities.

He showed improvements in the psychomotor aspects, as he carried out the pool entrances and exits with tranquility and autonomy. The exercises were done with greater coordination and less effort. In diving, he still presented resistance, but he performed apnea for longer and more frequently, with better respiratory control. After a more aggressive and impulsive time, the student appeared friendly and more sociable.

At the end of the study, he played quietly with other teachers and allowed other students to participate in the class. At certain times, he became impulsive when he felt frustrated, especially in relation to third parties. He expressed himself more verbally about his desires and listened better. He presented several demonstrations of affection with the teacher, in addition to better body awareness with the development of motor coordination, breathing, and relationship with other children and adults in the pool.

In the body expression, the student resisted the service, showing screams and stereotypes, showing great difficulty in accepting everything that seemed new such as the room, the Teacher, and the service proposal.

At the end of the study, the service was no longer individual, and the class structure was followed by him. Performed the activities with support but had the autonomy of movements in many moments. The class took place using the spaces in the room, different from his conduct at the beginning of the sessions when he was only interested in the small piano that the teacher used to convince him to enter. Gradually, he started to do what was asked, besides spontaneously proposing movements and, mainly, showing pleasure in being in class. His relationship with the other student who started to participate in classes with him from the third semester of the work proved to be effective, as it divided the teacher's space and attention without dramatizations or refusals.

Finally, he showed a great improvement in all aspects of his development, showing himself more body conscious. His notion and relationship with the space had improved, showing to be more adjusted in his social relations. He also showed affection and interest in people. In addition, he expressed a desire to participate in dance shows, and in the latter, he showed awareness of what he was doing on stage.

\section{Perceptions beyond the course}

A thorough behavioral assessment was performed by interviewing the mother and observing the student in the proposed sessions. Such evaluation did not use batteries of tests or quantitative data but following the perspective of Relational Psychomotricity and Henri Wallon's Theory, it considered the qualitative analysis of the behavior and the data presented by the mother.

The evaluation sought the aspects of behavior that should be used for the establishment of a link that would allow communication, considering what the student liked to do or not. For Grinker" 35 "the form of treatment, conferred to the Autistic body in specialized institutions, is focused on the training [...] in the name of the inability of abstraction of these individuals " since in many cases, it is mistakenly believed that the person with ASD needs to be trained by failing to understand teachers' stimuli and explanations.

Corroborating this issue, Vayer and Roncin ${ }^{36}$ stated that it is necessary to avoid authoritarian interventions, especially in the case of students who present maladaptations since they depending on the way others see and treat them, being more sensitive to such interventions, because "even if they are not traumatizing, always disrupt exercise and the development of self-assessment, therefore, the functional organization of information by the central nervous system" ${ }^{36}$. Thus, in the face of proposals that the student with ASD did not understand or did not accept, he/she tends to react negatively to the presence of the teacher, which leads to a lack of understanding by the central nervous system and failure to performed the proposal presented by the teacher, in addition to presenting sometimes aggressive reactions on the part of the student.

Thus, a first point considered was the expression of the student. ASD was not seen as a disabling disability, but as a condition that, despite causing limitations and bringing different behavioral characteristics, should not alienate people from those who have it. It focused on a human being like any other, with limitations, but with countless potentialities.

No concept of normality was considered, which it also excludes of any concept of abnormality. For Vayer and Roncin ${ }^{36}$, "it is the affective involvement in the adult-child relationship that causes the deviation from the definition, starting to be considered that the child is normal when it responds to what the adult expects of him". When the responses are not adequate to the wishes of the adults or the child's attitudes shock him, either because he does not understand them, or because he feels affected in his power, that child is considered unsuitable. Thus, for Vayer and Roncim ${ }^{36}$, "it is subjectivity in the relationship or observation that leads adults to decree that the child is poorly adapted or is considered abnormal".

Therefore, there was a need for teachers to be available for the educational action, which should provide an "atmosphere of sharing emotions, drives and desires", which can help the child "to have self-confidence and to like themselves, to express and express their feelings. feelings allowing him to approach a state of balance" ${ }^{\prime 37}$.

This availability could be seen when the Teacher, at the 
aquatic activities, offered his body at the beginning of the intervention so that the student could look for him when he felt like it, but also allowing him to move freely when he wished. The teacher showed to understand the desires of fusion and diffusion of the student who, initially, did not understand his presence. However, offering himself when required by the student who was afraid to dive and try certain movements in the water, he was available until this availability brought him into an emotional relationship.

The body expression teacher also respected the student's time and interests, creating a safe environment where affective bonds could be strengthened. Such a posture enabled him, even in an elementary way, to relate to other people.

There was an awareness that among the characteristics found in ASD are the difficulty of communication and establishing interpersonal relationships. According to $\mathrm{Bosa}^{38}$, "a more careful look and a careful listening allow us to discover the great effort that these children seem to make to use tools that help them to be understood". Therefore, the proposals presented initially sought to establish an affective relationship with the creation of bonds with students. For Wallon" "between individuals, it is the agreement or reciprocity of attitudes that are the first to be able to make a kind of contact and mutual understandings", and without this understanding, without a favorable bond for the student feels safe, there is hardly any learning.

Thus, the teachers' body availability was fundamental since the communication can only be established based on the body, posture, and motor representation shared and basic between them, is necessary that the teacher has "a fundamental capacity to know the other, his/her body, posture, attitude and proxemics, action and intention" 39 .

And perhaps it is in the impossibility of making itself understood in several situations, one of the main problems of TEA. For Quittlet and Garrido ${ }^{40}$, stereotypes and disorganized movements in the search to make themselves understood "despite being considered unsuitable, they are a means of communication". For the authors, people who present stereotypes and self-aggression, diminish or stop showing these behaviors when they discover other ways of communicating their desires to receive the same results that produced the problematic behavior. Therefore, the non-prohibition or restriction of the stereotypes presented.

In this sense, Tse, Pang and Lee ${ }^{10}$ pointed out the need for physical activity and psychomotor stimulation to reduce stereotypes, stating that they should not be banned, but respecting and monitoring their mechanics to obtain satisfactory behavioral results.

It was a question of proposing the education of students with ASD as it is due to all human beings and not their training. Therefore, the relational aspects were highlighted, considering that the child's self-elaboration process implies that the relational situation in which they live their experiences, facilitates and allows their activities that depend on two feelings: "the [...] of being in security and living the autonomy" 36 .

These two feelings are interconnected and interdependent because, when feeling safe, the individual can invest in the exploration of space through his body, which will bring her/ him greater autonomy, and consequently, more security for new investments.
With regard to people with ASD, who present the same conditions as the student in this study, the lack of experience with their body in space and, in many cases, the lack of understanding of the other in relation to their needs, create for them an insecure environment and, as a result, reactions occur, which are possible for them, presented in the form of aggression, tension, stereotypes, screams, among others.

According to Schenkelberg et al. ${ }^{41}$, the environment directly interferes with the level of physical activity of the children with ASD, depending on their configuration. In agreement with that, studies pointed out the need for a playful environment for the development of people with ASD through physical activity ${ }^{6,42}$.

Thus, we tried to make the environment safe, reliable, stable, and pleasant to the student. For this reason, the three conditions presented by Cunha ${ }^{43}$ were considered: anomie, heteronomy, and autonomy in relation to their movements. In anomie the child, wishing to satisfy his motor interests and his symbolic fantasies, embarks on activities that do not respect the collective rules. Here, we can insert the activities presented by the student at the beginning of the study, such as stereotypes, screams, and even aggressions. We can also consider in this aspect the refusal in relation to the teachers' proposals, as they were outside their capacity for understanding, being expressed by apparently disorganized movements, but which brought, in their core, a clear expression of the student's possibilities at that moment.

In addition, for Wallon ${ }^{24}$, "the situations in which the child reacts are exactly those corresponding to his means", that is, "he will interact with the environment according to his conditions and the impressions received the environment, depending on a certain behavior, will serve as a basis for its development".

For this reason, respect for the communication presented by the student was central to this work. Savage et al. ${ }^{44}$, in a study with people with ASD, proved the importance of praise and reinforcement for them and, thus, there was an understanding that, although verbal communication is a representation of human conscience, in front of people with ASD who have difficulty with verbalization, it is important to seek an understanding of what they have to say through their bodies and to value such communication.

Vieira et al. ${ }^{45}$ show that this bodily communication "is loaded with values and emotional components; the gesture, the look, the muscle tone speaks of our feelings, our fears, desires and conflicts, that is, the expression of the conscious and unconscious imaginary". He and Jespersen ${ }^{42}$ point to the need for body reciprocity with the student who has ASD, which means accepting their body communication. Thus, the student's gesture, even though it appears disorganized or unstructured, was not considered as a "simple nervous reaction to stimuli, but rather the response of a body to the world, that is, it is the representation of life in itself" 45 .

Initially, the proposal continued to allow the exercise of this possible body communication for the student, so that he could become aware of his own body, from the anomic exercises. But, in addition to allowing such exercises, teachers sought heteronomy, which is the moment when the individual "already perceives collective rules and, by imitation or by verbal contact, begins to play with the rules received from abroad" 43 a fact that has become extremely important for the student's development. 
After the establishment of the affective bond, when he realized the availability of the teachers and showed himself to be more available in relation to his proposals, they started to propose movements and gestures, contextualizing them. However, they did not charge for performance that disrespected or disfigured the student's conditions.

It was understood that the psychomotor dimension is a relevant aspect of non-verbal communication in the social environment for the person with ASD and that "the child coordinates his motor activity according to the mental image of the perceived act", being that "psychomotor therapy it facilitates, through its integrated programs, the education of the individual, aiming to know his own body and the identification of being" 46 .

One of the first results that could be seen about the teachers' performance in this sense was in the first dance show, held at the end of the first year of work when the student was present on the stage. Despite staying for a short time and even considering that he was accompanied by an adult, he has already managed to organize himself emotionally by making gestures determined by the teacher during the rehearsals, showing that he already understands his body better and the proposals presented to him.

In the two other dance shows, held at the end of each year of work, student participation has already been more effective, with less dependence and greater autonomy. He also participated in the four Swimming Festivals proposed from the third semester of work, showing the ability to relate to the other students since, at those moments, he shared the pool with about 120 people. In these festivals, the student, who in the first edition did not abandon the teacher and did not allow him to relate to other students, after the third event, began to show himself more autonomous in the pool, living well with his peers and with the Teachers, despite the hustle and bustle in the environment.

However, it could not be said that the student has achieved autonomy for his actions in the world. Nevetheless, we could say that there is already some autonomy in relation to this action. It should be considered that the methodology and procedures used by the teachers showed satisfactory results regarding the student's development, a fact that may point to the effectiveness of pedagogical interventions for people with ASD who use their bodies and movements as a way for their development and in the search for their autonomy.

It is possible to say that they were satisfactory in achieving their goals since a student, who was aggressive, aloof, with stereotypes and with several other characteristics that are attributed to people with ASD, after the pedagogical intervention, goes up on a stage and performs for an audience of about 800 people and with little or no help, presents choreographies created by the teacher; changes gestures and movements within these choreographies autonomously; shares a swimming pool, during the Swimming Festivals, with approximately 120 people without inappropriate attitudes; behaves accordingly in social environments; presents a considerable psychomotor development that allows him to carry out a series of activities in the pool in an autonomous way; proposes movements and games, plays, communicates, all of this in a way that is appropriate to different situations and much more effective than when he joined into the project.

\section{Notes of what didn't end}

It is believed that the achievements presented in this work point out the importance of the body proposals analyzed in the study, which stimulated, through the Workshops, synaptogenesis, and intercommunication between the various brain areas that are configured as one of the problems of TEA, which favors the development of communication and body scheme.

The association of activities performed in the liquid environment and body expression, proved to be relevant for the stimulation of a student with ASD, providing the necessary conditions for the development of psychomotor aspects, communication and social relations.

At the end of the study, it was noticed that the student presented a considerable development. In psychomotor aspects, in the activities of the Workshop Aquatic, managed to get in and out of the pool without help, slide and hit the legs of autonomously in the prone position and with the help of a plank in the supine position, in a coordinated way and with little effort, still presenting good control respiratory. In the activities of the body expression workshop, I was able to follow the proposals for the teacher's movements, in addition to proposing movements, presenting a considerable improvement in your body expression.

In relational aspects, he showed pleasure to be in the pool and dance, maintaining a good relationship with the other student who participated in the classes of body expression workshop with him, sharing the space and attention of the teacher without dramatizations or refusals. In the two workshops, he presented demonstrations of the affection for the teachers.

With regard to communication, he expressed himself verbally with greater clarity about his desires and listened better, showing affection and interest in people. Finally, he expressed the desire to participate in dance shows, and in the awareness of what he was doing on stage.

Despite the significant results presented in this study, it is necessary to propose a pedagogical intervention to more students with ASD, in order to get more conclusive information. This methodology of body approach that sought communication with a student with ASD, can also contribute to the understanding of other people who, given the difficulty of communication, could, from the permission of their expression, when they see understood and accepted, understand the environment and thus communicate, living with a social group.

To conclude that an integral perspective of the human being by performing corporal activities allows a better understanding of the environment, improved communication as well as would be more inclusive in this great and wonderful dance that is life.

\section{References}

1. DSM-V-TR. Diagnostic and statistical manual of mental disorders. Washington, DC, 2014.

2. Nichols C, Block ME, Bishop JC, McIntire B. Physical activity in young adults with autism spectrum disorder: Parental perceptions of barriers and facilitators. Autism. 2019; 23(6):1398-1407. doi: $10.1177 / 1362361318810221$. 
3. Bassette L, Kulwicki J, Dieringer ST, Zoder-Martell KA, Heneisen R. The Use of a Multicomponent Behavioral Intervention to Promote Physical Activity in Adolescents with Autism Spectrum Disorders across Inclusive Community Settings. Behav Anal Pract. 2018;11(4):358-369. doi: 10.1007/s40617-018-00285-7.

4. Yu CCW, Wong SWL, Lo FSF, So RCH, Chan DFY. Study protocol: a randomized controlled trial study on the effect of a gamebased exercise training program on promoting physical fitness and mental health in children with autism spectrum disorder. BMC Psychiatry. 2018;18(1):56. doi: 10.1186/s12888-018-1635-9.

5. Menear KS, Neumeir WH. Promoting Physical Activity for Students with Autism Spectrum Disorder: Barrier, Benefits and Strategies for Success. J Phys Educ Rec Dance. 2014; 86:43-48, doi: https//doi.org/10.1080/073084.2014.

6. Rafie F, Ghasemi A, Zamani Jam A, Jalali S. Effect of exercise intervention on the perceptual-motor skills in adolescents with autism. J Sports Med Phys Fitness. 2017; 57:53-59. doi: 10.23736/ S0022-4707.16.05919-3.

7. Bo J, Pang Y, Dong L, Xing Y, Xiang Y, Zhang M et al. Brief Report: Does Social Functioning Moderate the Motor Outcomes of a Physical Activity Program for Children with Autism Spectrum Disorders-A Pilot Study. J Autism Dev Disord. 2019; 49(1):415-421. doi: 10.1007/ s10803-018-3717-4.

8. Najafabadi MG, Sheikh M, Hemayattalab R., Memari AH, Aderyani MR, Hafizi S. The effect of SPARK on social and motor skills of children with autism. Pediatr Neonatol. 2018; 59(5):481-487. doi: 10.1016/j.pedneo.2017.12.005.

9. Toscano CVA, Carvalho HM, Ferreira JP. Exercise Effects for Children With Autism Spectrum Disorder: Metabolic Health, Autistic Traits, and Quality of Life. Percept Mot Skills. 2018; 125(1), 126-146. doi: 10.1177/0031512517743823.

10. Tse A, Pang CL, Lee PH. Choosing an Appropriate Physical Exercise to Reduce Stereotypic Behavior in Children with Autism Spectrum Disorders: A Non-randomized Crossover Study. J Autism Dev Disord. 2018; 48(5). doi: 10.1007/ s10803-017-3419-3.

11. Zachor DA, Vardi S, Baron-Eitan S, Brodai-Meir I, Ginossar, $\mathrm{N}$, Ben-Itzchak E. The effectiveness of an outdoor adventure programme for young children with autism spectrum disorder: a controlled study. Dev Med Child Neurol. 2017; 59(5):550556. doi: 10.1111/dmcn.13337.

12. Gao Z, Chen S, Sun H, Wen X, Xiang P. Physical Activity in Children's Health and Cognition. Biomed Res Int. 2018; 8542403. doi: 10.1155/2018/8542403.

13. Bremer E, Lloyd M. School-Based Fundamental-Motor-Skill Intervention for Children with Autism-Like Characteristics: An Exploratory Study. Adapt Phys Activ Q. 2015; 33(1):6688. doi 10.1123/APAQ.2015-0009.

14. Ferreira JP, Ghiarone T, Júnior CRC, Furtado GE, Carvalho HM, Rodrigues AM et al. Effects of Physical Exercise on the Stereotyped Behavior of Children with Autism Spectrum Disorders. Medicina (Kaunas). 2019; 14;55(10): E685. doi: 10.3390/medicina55100685.

15. Becchio C, Castiello U. Visuomotor resonance in autism spectrum disorders. Front Integr Neurosci. 2012; 6:110. doi: 10.3389/fnint.2012.00110.
16. Boato EM. Metodologia de Intervenção Corporal para Autistas. São Paulo: Edições Loyola, 2016.

17. Ketcheson L, Hauck J, Ulrich D. The effects of an early motor skill intervention on motor skills, levels of physical activity, and socialization in young children with autism spectrum disorder: A pilot study. Autism. 2017; 21(4):481-492. doi: 10.1177/1362361316650611.

18. Memari AH, Mirfazeli FS, Korki R, Shayestehfar M, Moshayedi P, Mansournia MA. Cognitive and social funtioning are connected to physical activity behavior in children with autismo spectrum disorder. Res Autism Spect Disord. 2017;33:21-28. doi: https:// doi.org/10.1016/j.rasd.2016.10.001.

19. Sotoodeh MS, Arabameri E, Panahibakhsh M, Kheiroddin F, Mirdoozandeh H, Ghanizadeh A. Effectiveness of yoga training program on the severity of autism. Complement Ther Clin Practe. 2017; 28:47-53. doi: 10.1016/j.ctcp.2017.05.001.

20. Wallon H. Psicologia e Educação da Infância. Lisboa: Editorial Estampa, 1975.

21. Wallon H. A Evolução Psicológica da Criança. $4^{\mathrm{a}}$. ed. Lisboa: Edições 70, 2005.

22. Wallon H. As origens do pensamento na criança. São Paulo: Manole, 1989.

23. Wallon H. Do ato ao pensamento. Lisboa: Portugália Editora, 1981.

24. Wallon H. As origens do caráter na criança. São Paulo: Difusão Européia do Livro, 1971.

25. Lapierre A, Aucouturier B. Fantasmas corporais e Prática Psicomotora. São Paulo: Manole, 1984.

26. Lapierre A, Aucouturier B. Associações de Contrastes: Estruturas e Ritmos. São Paulo: Editora Manole, 1985.

27. Lapierre A, Aucouturier B. Bruno: Psicomotricidade e Terapia. Porto Alegre. Artes Médicas, 1986.

28. Lapierre A, Aucouturier B. A simbologia do movimento humano: Psicomotricidade e Educação. Porto Alegre: Artes Médicas, 1988.

29. Lapierre A, Aucouturier B. A Educação Psicomotora na escola maternal: Uma experiência com os "pequeninos". São Paulo: Editora Manole, 1989.

30. Gutierres Filho P, Andrade A. Da Hidroterapia a Psicomotricidade Relacional em Meio Aquático. Coleção Pesquisa em Educação Física. 2007; 5(1):207-214.

31. Boato EM, Diniz SV, Sampaio TMV. Vale Encantado: Educação Física e Arte-educação construindo juntas um espaço de "com-vivências". In: XVII Congresso Brasíleiro de Ciências do Esporte. 2011. Porto Alegre: UFRGS, 2011. pp. 01-15.

32. Le Boulch J. O desenvolvimento psicomotor: do nascimento até 6 anos. Porto Alegre: Artes Médicas, 1992.

33. Yin R. Estudo de Caso. Planejamento e Métodos. Porto Alegre: Bookman, 2005.

34. Denzin NK, Lincoln YS. Handbook of qualitative research. Thousand Oaks (CA): Sage Publications, 1994.

35. Grinker RR. Autismo: um mundo obscuro e conturbado. São Paulo: Larousse, 2010.

36. Vayer P, Roncin C. Integração da Criança Deficiente na Classe. Lisboa: Instituto Piaget, n.d.

37. Boato EM. Introdução a Educação Psicomotora: A vez e a voz do corpo na escola. Brasília: IEPSE, 2012. 
38. Bosa CA. Autismo: atuais interpretações para antigas observações. In: Batista CR, Bosa CA(Org). Autismo e Educação: Reflexões e propostas de intervenção. Porto Alegre: Artmed, 2012.

39. Fonseca V. Psicomotricidade e neuropsicologia: uma abordagem evolucionista. Rio de Janeiro: Wak Editora, 2010.

40. Quittlet PR, Garrido MJ. G. Personas com retraso mental y problemas de comportamiento. El estado de La custión. Revista de Servicios Sociales. 1991; n. 17.

41. Schenkelberg MA, Rosenkranz RR, Milliken GA, Dzewaltowski DA. Social Environmental Influences on Physical Activity of Children with Autism Spectrum Disorders. J Phys Act Health. 2015; 12:636-641. doi: 10.1123/jpah.2013-0312.

42. He J, Jespersen E. The Embodied Nature of Autistic Learning: Implications for Physical Education. Phys Cult Sport Stud Res. 2015; v.65, ed.1, pp. 63-73. doi: 10.1515/pcssr -2015-0012.

43. Cunha E. Autismo e Inclusão. Psicopedagogia e práticas educativas na escola e na família. 3a. ed. Rio de Janeiro: Wak Editora, 2011.

44. Savage MN, Taber-Doughty T, Brodhead MT, Bouck EC. Increasing physical activity for adults with autism spectrum disorder: Comparing in-person and technology delivered praise. Res Dev Disabil. 2018; 73:115-125. doi: 10.1016/j.ridd.2017.12.019.

45. Vieira JL, Bellaguarda MI, Lapierre A. Psicomotricidade Relacional: a teoria de uma prática. $2^{\mathrm{a}}$. ed. Curitiba: CIAR, 2005.
46. Barna I. Developing Psychomotor Skills in the case of Autistic Students. EpSBS. 2017; 23:1786-1794. doi: 10.15405/ epsbs.2017.05.02.2019.

\section{Corresponding author}

Elvio Marcos Boato

Rua Buriti Lote 01 Ap. 405, Águas Claras, Brasília, DF. 71940-000

Email: elvioboato@gmail.com

Associate Editor: Giselle H Tavares. UFU/Uberlandia, MG, Brazil

Manuscript received on April 29, 2020

Manuscript accepted on July 16, 2020

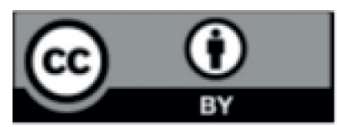

Motriz. The Journal of Physical Education. UNESP. Rio Claro, SP, Brazil - eISSN: 1980-6574 - under a license Creative Commons - Version 4.0 